\title{
SETTING PERILAKU DALAM EVALUASI PURNA HUNI (EPH) GEDUNG DIREKTORAT POLITEKNIK NEGERI PONTIANAK
}

\section{Ferry Kurniadi}

Jurusan Teknik Arsitektur, Politeknik Negeri Pontianak

urban.recofery@gmail.com

\section{Dian Perwita Sari}

Jurusan Teknik Arsitektur, Politeknik Negeri Pontianak

dianperwita.ars@gmail.com

\section{Taufik Wibowo}

Jurusan Teknik Arsitektur, Politeknik Negeri Pontianak

Sandtafix@gmail.com

\begin{abstract}
Abstrak
Gedung Direktorat merupakan wajah depan kampus yang memberikan citra bagi kampus tersebut. Gedung Direktorat Politeknik Negeri Pontianak adalah bangunan yang pada perkembangannya mengalami penurunan kualitas fisik bangunan. Penurunan performa bangunan tersebut dilihat terutama terlihat dari aspek perilaku (behavior), sehingga diperlukanlah sebuah evaluasi purna huni (EPH) untuk menilai performasi aspek tersebut. Penelitian ini bertujuan mengidentifikasi performansi dari aspek perilaku yang dibentuk oleh tata layout ruang pada Gedung Direktorat Politeknik Negeri Pontianak yang kemudian dianalisa untuk mendapatkan temuan yang dapat digunakan untuk perencanaan dan redesain pembangunan gedung ini di masa yang akan datang. Metode yang akan digunakan adalah metode penelitian kualitatitif yang dilakukan secara investigatif dengan menggunakan analisa metode pemetaan perilaku berupa person centered mapping, place centered mapping, physical trace. Hasil dari penelitian ini berupa penilaian terhadap performansi ruang yang ditimbulkan akibat setting perilaku yang dilihat dari pemetaan perilaku berupa teritori, ruang personal dan privasi. Setting perilaku pada bangunan dipengaruhi oleh pergerakan pengguna dan aksesbilitas di dalam bangunan.
\end{abstract}

Kata-kata Kunci: EPH, Setting, Perilaku, Person Centered Mapping, Place Centered Mapping, Physic Trace

\section{BEHAVIOR SETTING IN POST OCCUPANCY EVALUATION (POE) OF DIRECTORATE OF PONTIANAK STATE POLYTECHNIC BUILDING}

\author{
Abstract \\ The Directorate Building is the front facade of the campus, which gives an image for the whole \\ campus. Pontianak State Polytechnic Directorate Building in its development experienced a \\ decreasing quality. One of the declines in building performance could see from the behavior aspect,
}


so it needs a post-occupancy evaluation (POE) to assess this aspect's performance. This study aims to identify the performance of behavioral factors forming by the spatial layout in the Pontianak State Polytechnic Directorate Building, then analyzed to obtain findings that could use to plan and redesign this building in the future. The research method is a qualitative research method, carried out investigative using analysis of behavioral mapping methods such as person-centered mapping, place centered mapping, and physic trace. The result of this study is an assessment of the spatial performance that results from the behavior setting that seeing from the behavior mapping like territory, personal space, and privacy. Behavior settings influenced by the user movement and accessibility within the building.

Keywords: POE, Setting, Behavior, Person Centered Mapping, Place Centered Mapping, Physic Trace

\section{Pendahuluan}

Sebuah bangunan sebagai karya arsitektur menempati lokasi tertentu lengkap dengan sistem, alat, dan ruang yang berfungsi untuk mendukung aktivitas manusia. Dirangkum dari Hay et al. (2018), Evaluasi purna huni (EPH) secara umum adalah kegiatan "pembelajaran" dan meningkatkan kualitas desain atau rancangan melaui kegiatan evaluasi. EPH digunakan untuk mengisi "kekosongan" performansi aktual bangunan berbanding dengan rancangan awal. EPH juga merupakan alat untuk mengenali dan menginvestigasi bagaimana dan mengapa bangunan tidak sesuai dengan harapan Arsitek atau Perencana. Masih dirangkum oleh Hay et al. (2018) EPH dapat diaplikasikan dalam evaluasi kualitas dan standar dari desain dan konstruksi bangunan.

Adapun kegiaan evaluasi fasilitas dalam metode evaluasi purna huni ini melibatkan penilaian yang sistematis, dimana terdapat dua tujuan penilaian yakni (Pena, 2001)

1. Untuk mendeteksi, mengamati, dan melaporkan secara akurat kondisi yang ada dan perubahanperubahan yang terjadi terhadap kondisi asalnya atau yang diwakili oleh indikasi/tujuan dalam program.

2. Untuk memodifikasi faktor-faktor pada program dan atau kriteria desain, untuk merekomendasikan tindakan korektif, dan menjadi masukan bagi proses pemrograman, merancang, membangun, dan mengelola gedung-gedung, baik untuk kasus yang sama (lanjutan) atau kasus yang lain yang serupa.

Terdapat 3 (tiga) kategori elemen performansi bangunan untuk melaksanakan evaluasi purna huni $(\mathrm{EPH})$. Antara lain:

1. Aspek Teknikal

Aspek teknikal dapat menjadi ciri latar belakang lingkungan pengguna beraktifitas. Aspek teknikal meliputi: struktur, sanitasi, dan ventilasi, keselamatan, kebakaran, elektrikal, dinding eksterior, finishing interior, atap, akustik, pencahayaan, dan sistim kontrol lingkungan (Preiser, 1998).

2. Aspek Fungsional

Organisasi yang menempati gedung mengaharapkan memperoleh kepuasan dari gedung tersebut karena kinerja fungsionalnya. Aspek Fungsional meliputi faktor manusia, penyimpanan, komunikasi, dan alur kerja, fleksibilitas dan perubahan, spesialisasi dalam tipe atau unit bangunan (Preiser, 1998).

3. Aspek Behavioral/perilaku

Aspek behavioral dari performansi menghubungkan antara aktivitas dan kepuasan pengguna dengan lingkungan fisik. Aspek behavioral meliputi proksemik, teritorilitas, privasi, interaksi, presepsi lingkungan, citra dan makna, kognisi dan orientasi lingkungan (Preiser, W.F.E., 1998). 
Evaluasi purna huni secara umum mempunyai 3 pendekatan (Pizzuti-Ashby, 2013), yaitu indikatif, investigatif, dan diagnosis. Pendekatan indikatif biasanya dilakukan dalam beberapa jam yang dilakukan dengan mengamati dan menyebarkan kusioner dasar. Tujuannya untuk mendapatkan kekuatan dan kelemahan bangunan. Pendekatan kedua yaitu investigatif adalah pendekatan yang lebih komplek dengan berbagai data dan cara, termasuk interview, forum grup discussion (FGD), dan survey. Pendekatan investigatif dapat dilakukan selama 3 sampai 5 bulan. hasilnya akan memberikan gambaran kondisi dan rekomendasi peningkatan performa. Pendekatan yang terakhir adalah EPH diagnosis. Pada pendekatan ini kegiatan EPH dapat dilakukan antara 6-12 bulan dengan metode interview, survei untuk menilai fungsi-fungsi lingkungan binaan. Evaluasi purna huni yang telah dilakukan pada satu tahun akan masuk dalam tahap project review. Blyth, A \& Gilby, A (2006) senada dengan Soedibyo (1989) dalam Hadi Wijaya (2018) memberikan penjelasan bahwa pada project review yang mencangkup aspek fungsional dapat dilakukan dengan metode observasi, pemetaan, pengukuran langsung dan menggunakan literatur ataupun standar sebagai patokan. Adapun penyelesaian aspek teknis dapat dilakukan dengan metode investigatif, yaitu melakukan melakukan observasi, pengukuran, penilaian berdasarkan literatur.

Evaluasi perilaku berkaitan dengan kesejahteraan sosial dan psikologis pemakai yang dipengaruhi oleh rancangan bangunan. Permasalahan perilaku yang perlu diperhatikan seperti proximity dan teritoriality, privacy dan interaksi, persepsi, citra dan makna, kognisi dan orientasi. Fenomena perilaku merupakan bentuk interaksi antara manusia dengan lingkungan (setting) fisik. Dari bentuk interaksi akan menghasilkan apa yang disebut atribut. Atribut adalah kualitas lingkungan yang dirasakan sebagai pengalaman manusia, merupakan produk organisasi, individu, dan setting fisik (Weisman dalam Syafriani, 2015).

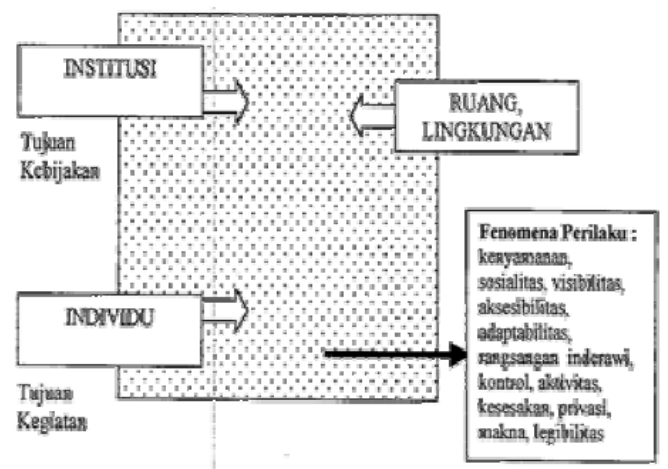

Gambar 1. Model Sistem Perilaku-Lingkungan (PxE) Sumber: Weisman dalam Syafriani, 2015

Konteks lingkungan perilaku tidak lepas dari konteks berinteraksi. Menurut Nugraha (2013) Interaksi melibatkan manusia sebagai pelaku dan lingkungan atau sesuatu diluar dirinya sebagai latarnya. Manusia terdiri dari individu yang beragam sedangkan latar merupakan benda diluar individu yang dapat dimodifikasi oleh individu. Di sisi lain, bahwa manusia sebagai individu juga merupakan pribadi yang sangat kompleks, selain dapat berinteraksi dengan sesamanya individu dan dengan latarnya juga dapat berinteraksi dengan jiwa dalam dirinya. Jika dibawa ke konteks ruang arsitektur maka manusia adalah pelaku interaksi lintas ruang. Hasil-hasil dari interaksi tersebut kemudian dapat dilihat pada perwujudan desain sepanjang ruang hidupnya, mulai dari desain pakaian, desain rumah, desain ruang kota dan sebagainya.

Politeknik Negeri Pontianak merupakan Perguruan Tinggi jalur vokasional dipimpin oleh seorang Direktur dan tempat pengelolaan kelembagaannya disebut Direktorat, Direktorat dari asal katanya menurut KBBI (Kbbi.co.id, 2019) bagian dari departemen yang tugasnya mengurus suatu 
bidang tertentu, dikepalai oleh seorang direktur. Gedung Direktorat juga biasa dikenal dengan Gedung Akademik.

Bangunan Gedung Direktorat Polnep telah berdiri lebih dari 5 (lima) tahun, kondisi fisik bangunan gedung pun sudah mulai menurun, beberapa elemen bangunan sudah mulai terlihat rusak, kesan kotor dan kumuh, dan beberapa ruang tidak sesuai dengan sirkulasi yang ingin dicapai. Mengingat kondisi gedung direktorat yang ada saat ini sudah tidak memungkinkan menampung unitunit kelembagaan yang telah berkembang dari sejak awal berdirinya. Dan banyak unit-unit lembaga yang digabung dalam satu ruangan ataupun ditumpangkan ke gedung-gedung jurusan, bahkan beberapa unit masih belum memenuhi standar minimal besaran ruang yang disyaratkan. Dalam rangka pembenahan dan pengembangan kembali fasilitas-fasilitas di Gedung Direktorat Polnep ini diperlukan metode evaluasi pasca huni terhadap fasilitas dan prasarana-sarana fisik, agar langkah-langkah pengembangan fasilitas fisiknya dapat lebih menemui sasarannya pada masa mendatang terutama aspek aktifitas pengguna.

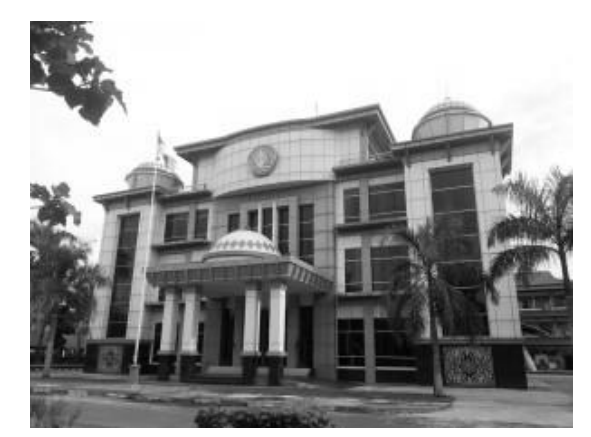

Gambar 2. Gedung Direktorat Politeknik Negeri Pontianak

Sumber: Penulis, 2019

Evaluasi purna huni kelayakan layout ruang atas aktifitas perilaku pengguna bangunan Gedung Direktorat Polnep diperlukan saat ini mengingat ruang eksisting tidak sesuai dengan architectural programming dan perencanaan awal. Ruang-ruang yang berada pada bangunan gedung Direktorat Polnep tidak terintegrasi antara satu ruang dengan ruang lainnya. Hal ini membuat aktifitas pelaku hanya terfokus pada ruang-ruang tertentu, sehingga tidak menyebar secara sempurna. Dari sini dapat dilihat indikasi ruang-ruang tidak berfungsi secara optimal dan menghabiskan banyak ruang untuk sirkulasi. Ruang-ruang yang tidak terkoneksi dan terintegrasi dengan baik pada gedung Direktorat Polnep dapat menjadi ruang "mati".

Tujuan dari penelitian ini adalah mengevaluasi performa Gedung Direktorat Politeknik Negeri Pontianak dilihat dari aktifitas dan setting perilaku guna mengetahui seberapa besar kesenjangan antara eksisting dari fasilitas ruang Gedung Direktorat Polnep dengan kriteria perilaku yang berlaku. Selain itu, penelitian ini juga bertujuan untuk menganalisis kualitas ruang dan kapasitasnya yang perlu dikembangkan pada masa mendatang terutama dalam analisa perilaku (behaviour analysis). Hasil dari studi ini, diharapkan dapat menjadi salah satu sumber rujukan Direktorat dan bagian Akademik Polnep untuk meningkatkan kualitas sarana dan sarana bangunan, sehingga dapat meningkatkan kualitas bangunan. Dan sebagai bahan referensi apabila di masa yang akan datang Gedung Direktorat Polnep akan melakukan rehabilitasi.

\section{Metode Penelitian}

Metode penelitian yang digunakan adalah investigatif dengan menggunakan metode penelitian kualitatif. Menurut Creswell (2007) dalam Syafriani (2015), penelitian kualitatif merupakan metodemetode untuk mengeksplorasi dan memahami makna yang oleh sejumlah individu atau sekelompok 
orang dianggap berasal dari masalah sosial atau kemanusiaan. Metode penelitian ini dibantu dengan menggunakan pengamatan perilaku yang dikembangkan oleh Zeisel (1981) yaitu dengan pengamatan perilaku (Observing Behaviour) dan pemetaan perilaku (behavior mapping), di samping itu ditambahkan dengan metode wawancara. Lokus penelitian adalah Gedung Direktorat Politeknik Negeri Pontianak. Dalam penelitian ini peneliti hanya akan menganalisis dan membahas Evaluasi Purna Huni Gedung Direktorat Politeknik Negeri Pontianak sebatas aspek behavioral/perilaku mengingat keterbatasan waktu penelitian, sedangkan aspek teknikal dan fungsional akan dikembangkan untuk penelitian di masa akan datang. Tahapan penelitian menggunakan metode pemetaan perilaku atau yang biasa disebut (behavior mapping). Behavior mapping mempunyai kekuatan utama dalam aspek spasialnya.

Behavior Mapping adalah penggambaran perilaku dan penggambaran pemakainya serta penentuan - penentuan perilaku pada pusat fisiknya (phsycal locus). Pemetaan perilaku adalah salah satu teknik survei untuk kajian arsitektur perilaku, menurut Sommer (1986) dalam Siregar (2017) bahwa pemetaan perilaku dapat digambarkan dalam bentuk sketsa atau diagram mengenai suatu area dimana manusia melakukan berbagai kegiatannya, tujuan nya sendiri adalah untuk menggambarkan perilaku dalam peta, mengidentifikasikan jenis dan frekuensi perilaku, serta menunjukan kaitan antara perilaku pengguna dengan ruang yang spesifik dari place centered mapping, person centered mapping, dan physical trace yang digambarkan dalam bentuk sketsa atau diagram.

Pada studi ini penelitian dibagi menjadi dua tahapan penelitian. Tahapan yang pertama menganalisa menggunakan metode place centered mapping secara kualitatif dengan menggunakan atribut prilaku yaitu privasi, ruang personal dan teritori. Penelitian kedua menggunakan metode person centered mapping yang dilakukan secara kuantitatif dengan menggunakan simulasi space syntax yang digambarkan secara terukur dengan software dephtmap. Di dalam penelitian ini yang difokuskan adalah Analisa Place Center Mapping, sedangkan Analisa person center mapping beserta simulasinya dibuat dalam penelitian terpisah dari penelitian ini.

Metode Pengumpulan data dilakukan dengan metode observasi lapangan, wawancara dan kuesioner. Observasi lapangan dilakukan untuk menggali data-data fisik objek penelitian, seperti pemetaan denah bangunan, serta pola-pola aktivitas pengguna bangunan. Sedangkan metode wawancara dan kuesioner akan digunakan untuk menggali informasi-informasi non fisik, seperti tingkat kepuasan serta harapan-harapan pengguna. Alur penelitian digambarkan dalam diagram di bawah ini. 


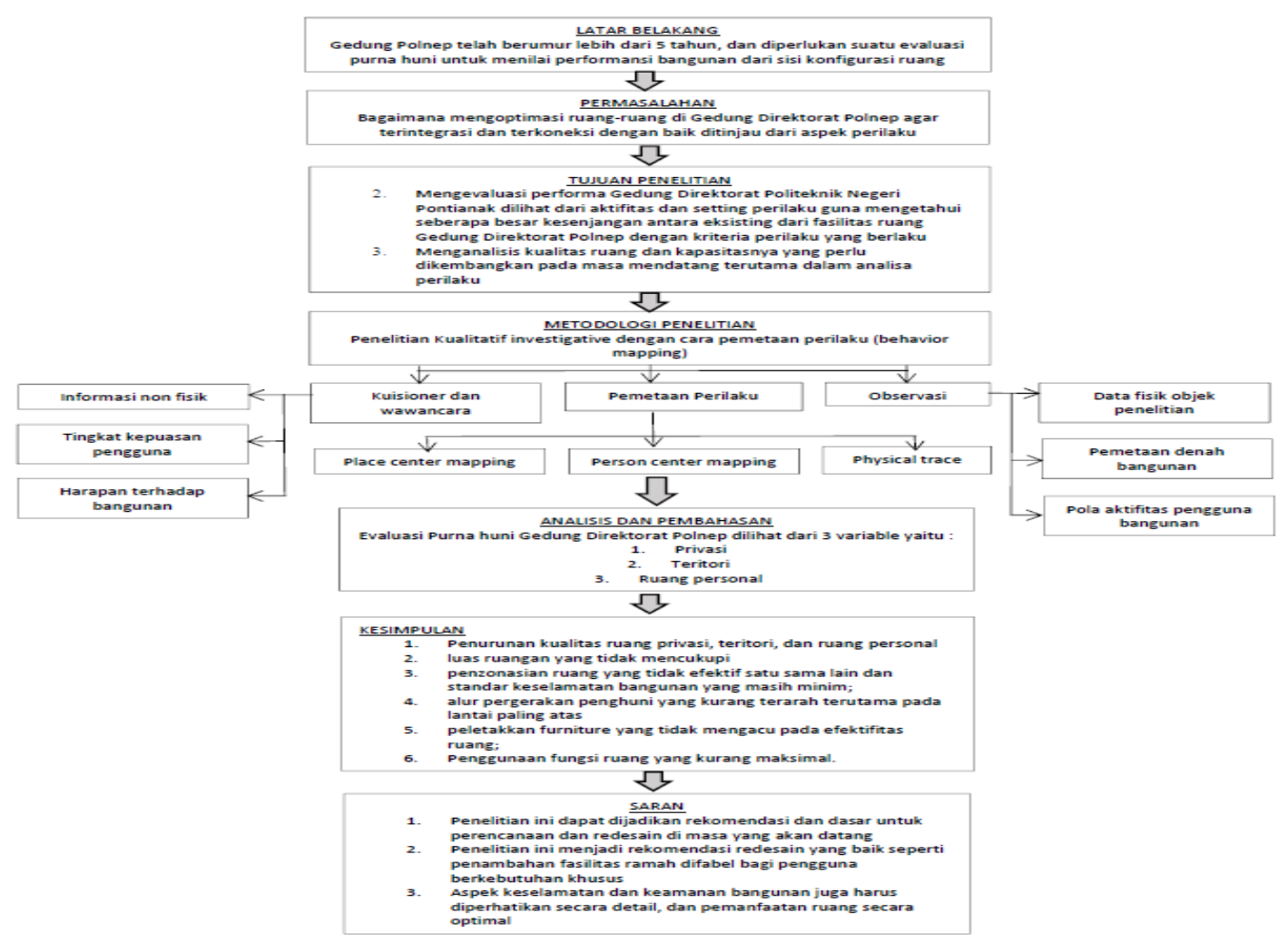

Gambar 3. Diagram alur penelitian Sumber: Penulis, 2019

\section{Hasil dan Pembahasan}

Gedung Direktorat Polnep adalah bangunan yang terdiri 4 lantai. Lantai dasar digunakan sebagaian besar untuk kegiatan Tata Usaha, dan Unit Penelitian dan Pengabdian Masyarakat (UPPM) dan Informasi yang dizonasikan pada sisi sebelah kiri bangunan. Pada sisi sebelah kanan Bagian Akademik Kemahasiswaan. Zonasi servis diletakkan pada sisi tangga. Akses menuju lantai atas hanya terdapat 1 jalur tangga. Lantai 2 difungsikan sebagai zona pejabat struktural Polnep, mulai dari Direktur, Wakil Direktur (Wadir), bagian Keuangan, Bagian Kepegawaian, dan Unit Kerjasama Hubungan Internasional (UKHI). Keseluruhan ruang-ruang tersebut mengelilingi area service yaitu tangga dan toilet. Ruang-ruangan tersebut juga dikoneksikan oleh koridor dengan lebar 2 meter.

Lantai 3 dizonasikan untuk kegiatan senat dan rapat, terdapat ruang PPK, dan Satuan Pengawas Internal, kerumah tanggaan. Keseluruhan ruang yang ada di lantai 3 dibuat mengelilingi area service yaitu tangga dan toilet dengan lebar koridor kurang lebih 2 meter. Sedangkan lantai paling atas yaitu lantai 4 dizonasikan hanya untuk 2 kegiatan yaitu PT Di luar Domisili (PDD) Kapuas Hulu dan Program Studi Di Luar Kampus Utama (PSDKU) Sanggau.

\section{Data Eksisting Bangunan}

Lantai 1 terdiri dari 14 ruang yang digunakan untuk kegiatan direktorat. Pada sisi bagian belakang sebagian lantai digunakan untuk area parkir mobil. Akses pintu masuk terdiri dari 2 jalur, yaitu jalur depan dan entrance utama dari sisi depan. Lantai 2 terdiri dari 24 ruangan yang tersebar di seluruh lantai. Peruntukkan fungsi lantai digunakan untuk pejabat structural seperti Direktur, Wakil Direktur, Keuangan dan lain-lain. 


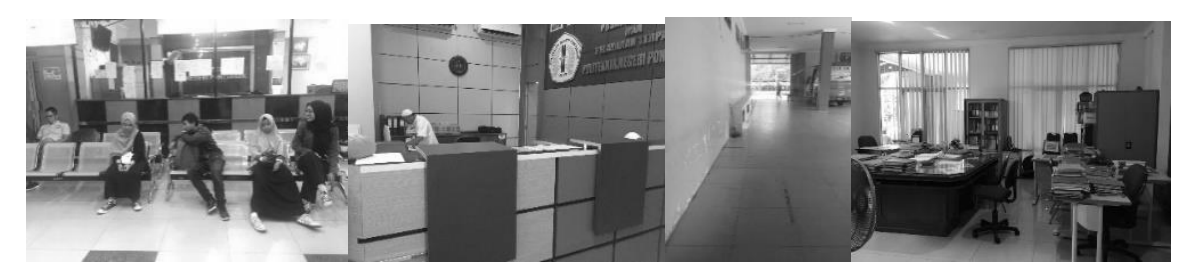

Gambar 4. Situasi di Lantai 1

Sumber: Penulis, 2019
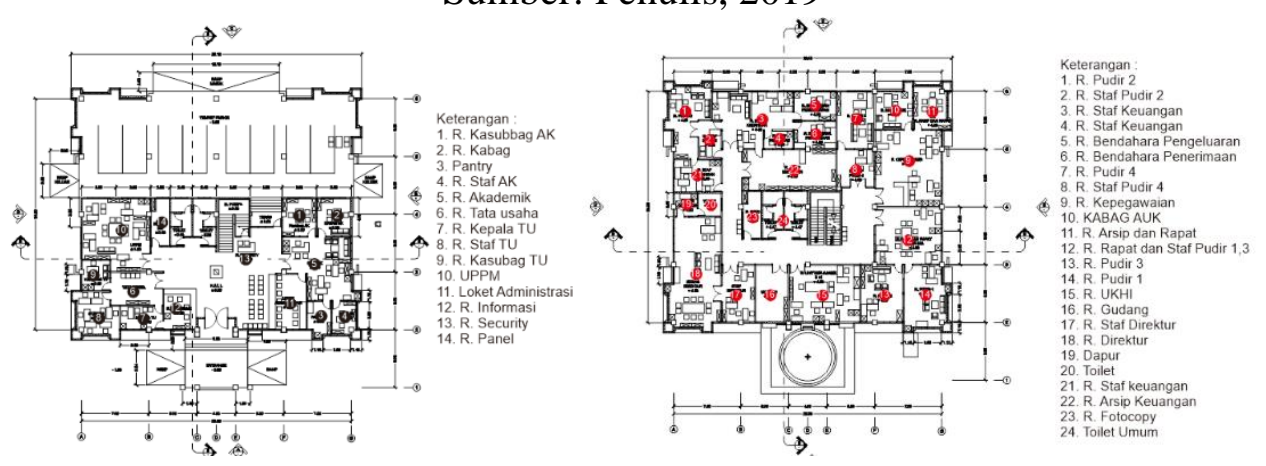

Gambar 5. Denah Lantai 1 dan 2 Gedung Direktorat Polnep

Sumber: Penulis, 2019

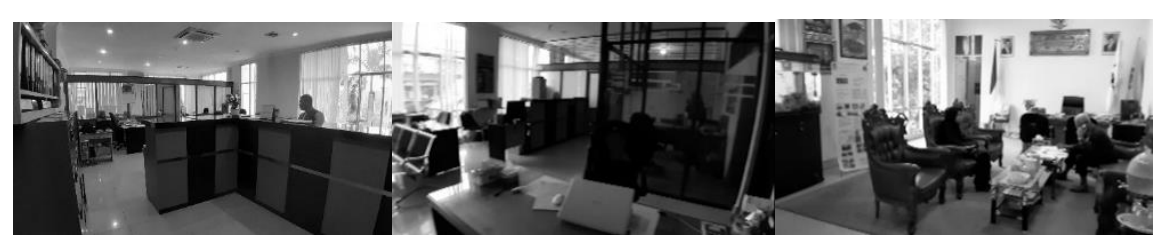

Gambar 6. Situasi Ruang Di Lantai 2

Sumber: Penulis, 2019

Lantai 3 terdiri dari 10 ruangan. Peruntukkan ruang sebagian besar digunakan untuk kegiatan rapat, penyimpanan arsip dan ruang-ruang pengawas internal. Lantai 4 terdiri dari 4 ruangan. Secara keseluruhan ruangan pada lantai ini difungsikan untuk ruang direktur PDD dan PSDKU.

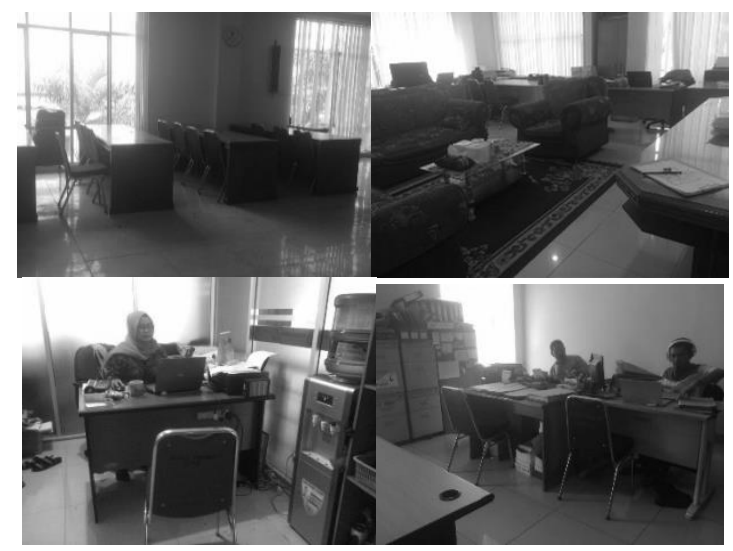

Gambar 7. Atas, Ruang Rapat Dan Ruang PSI (Lantai 3). Bawah, Suasana Ruang Di Lantai 4 Sumber: Penulis, 2019 

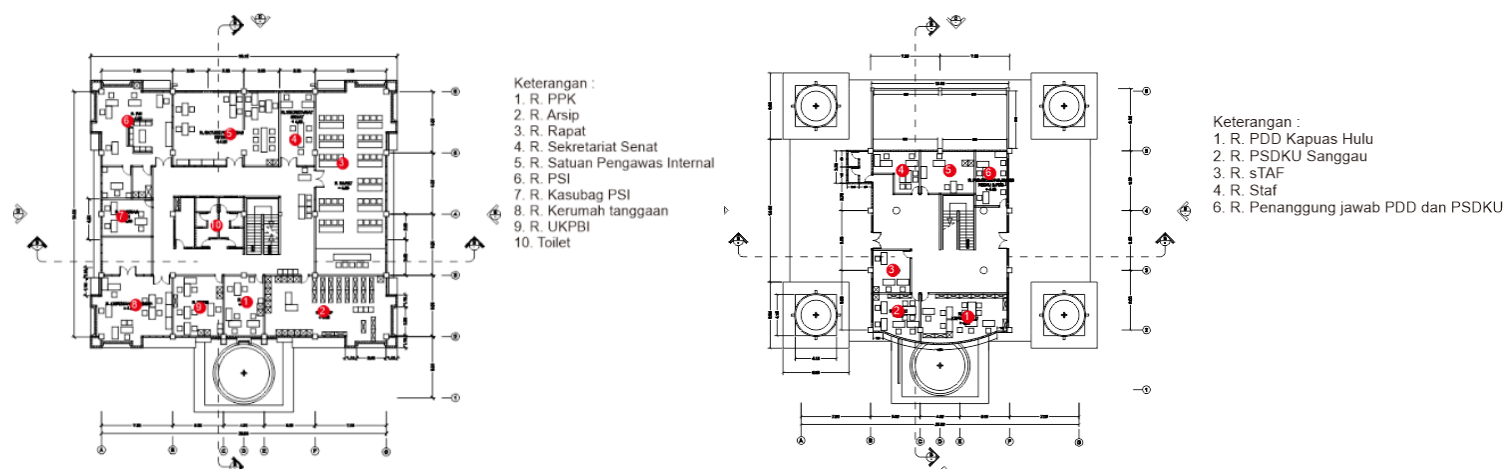

Gambar 8. Denah Lantai 3 dan 4 Gedung Direktorat Polnep

Sumber: Penulis, 2019

Dari gambaran kondisi layout denah eksisting di atas kemudian dibuat pemetaan perilaku berdasarkan place centered mapping, person centered mapping dan physical trace. Dalam penelitian ini pembahasan dan analisa hanya difokuskan pada pemetaan place centered mapping dan physical trace, untuk person centered mapping akan dilanjutkan pada penelitian selajutnya dimana menggunakan analisa dan simulasi space syntax. Penelitian perilaku dilakukan selama 3 hari dalam seminggu yaitu pada hari Senin (awal minggu), hari Rabu (tengah minggu) dan hari Jumat (akhir minggu). Dalam 1 hari pengamat melakukan 3 kali pengamatan masing-masing selama 1 jam. Waktu yang diambil untuk pengamatan antara lain pukul 09.00-10.00, pukul 12.00-13.00 dan pukul 15.3016.30. Adapun pemetaan perilaku masing-masing lantai dapat dilihat pada tabel berikut ini.

Tabel 1. Pemetaan Place Centered Mapping dan Physical Trace Pada Hari Senin

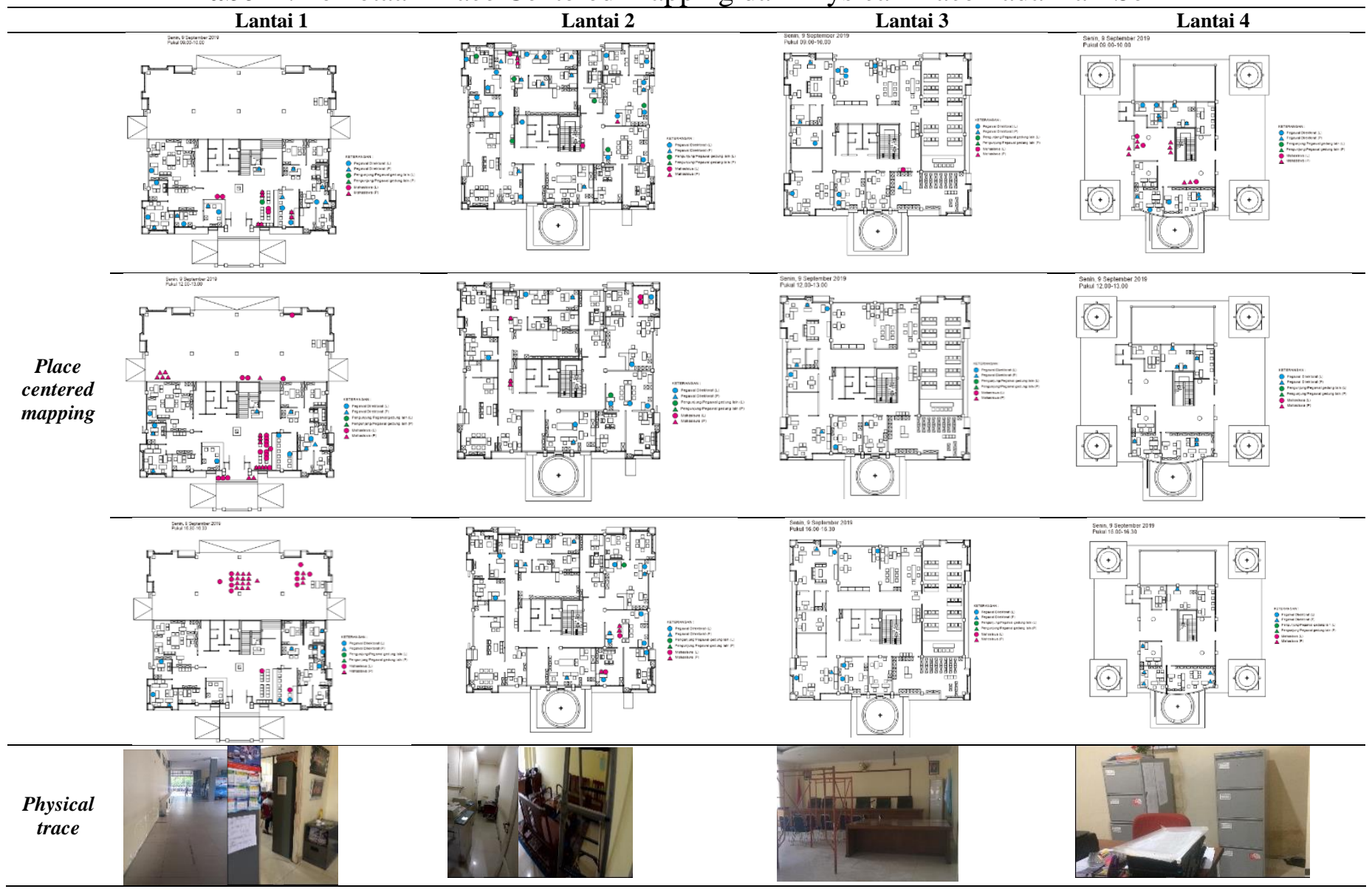

Sumber: Penulis, 2019 
Tabel 2. Pemetaan Place Centered Mapping dan Physical Trace Pada Hari Rabu

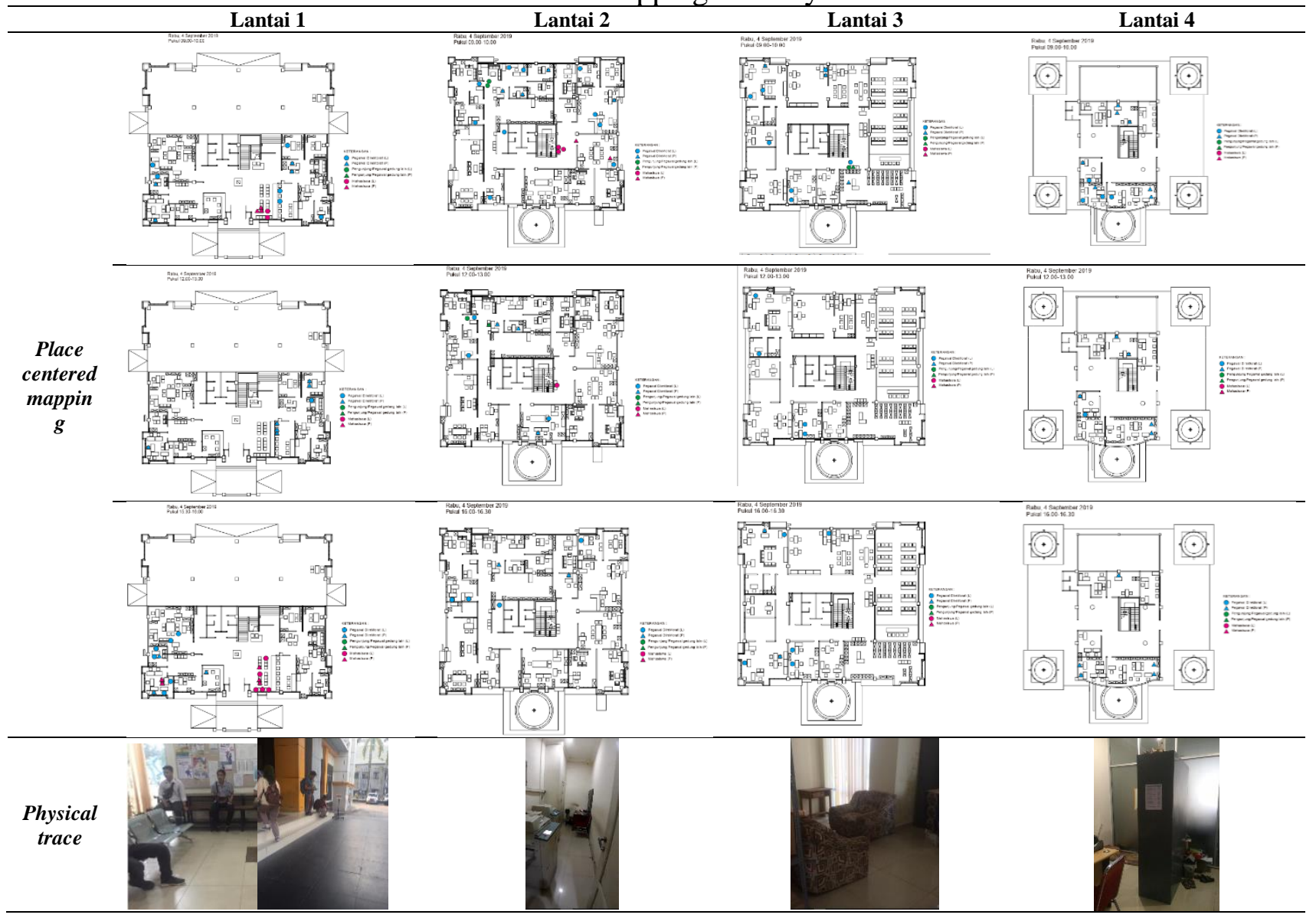

Sumber: Penulis, 2019

Tabel 3. Pemetaan Place Centered Mapping dan Physical Trace Pada Hari Jumat

Lantai 1 Lantai 2




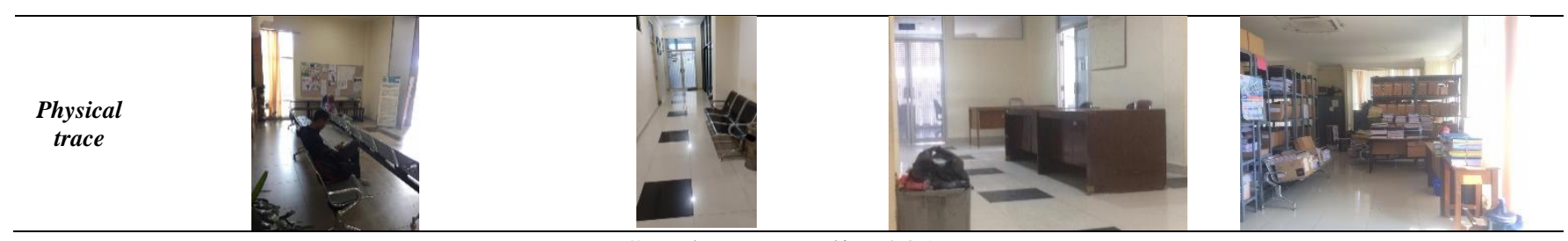

Sumber: Penulis, 2019

Tabel 4. Simbol pelaku Gedung Direktorat Polnep

\begin{tabular}{lll}
\hline No & Simbol & \multicolumn{1}{c}{ Keterangan } \\
\hline 1 & Pegawai Direktorat (Laki-laki) \\
\hline 2 & Pegawai Direktorat (Wanita) \\
\hline 3 & $\begin{array}{l}\text { Pengunjung/Pegawai Gedung lain (Laki- } \\
\text { laki) }\end{array}$ \\
\hline 5 & $\begin{array}{l}\text { Pengunjung/Pegawai Gedung lain } \\
\text { (wanita) }\end{array}$ \\
\hline 6 & \begin{tabular}{l} 
Mahasiswa (Laki-laki) \\
\hline
\end{tabular} & Mahasiswa (wanita) \\
\hline
\end{tabular}

Sumber: Penulis, 2019

Pada Tabel 1 menunjukkan alur pengguna bangunan di setiap lantai Gedung Direktorat Polnep. Hari Senin pagi dari data lapangan didapatkan bahwa setiap ruang di masing-masing lantai digunakan dengan sangat baik, artinya setiap ruang di masing-masing lantai terdapat penggunjung di dalamnya. Pada lantai 1 ruang-ruang yang paling ramai adalah ruang tunggu, ruang pusat informasi, dan ruang bagian akademik. Pada lantai 2 menunjukkan area yang padat pengunjung adalah di ruang bagian keuangan, ruang Pudir 3 dan 4, serta ruang tunggu di depan ruang Pudir 1 dan 2. Di lantai 3 ruang satuan pengawas internal, ruang UKPBI adalah ruang-ruang yang setiap hari senin pagi terdapat orang di dalamnya, pada koridor sepanjang ruang lantai 2 terdapat beberapa mahasiswa yang menunggu. Sedangkan pada lantai 4 mahasiswa berkumpul di hall, dan setiap ruang terdapat pegawai. Menjelang jam istirahat siang yaitu pukl 12.00 suasana ruang di lantai 1 menjadi lebih ramai dikarenakan mahasiswa berkumpul di area ruang tunggu, serta area parkir di belakang lantai 1 . Beberapa pekerja hanya terlihat dengan jumlah yang lebih sedikit dibandingkan di pagi hari. Pada lantai 2 hampir semua ruang menjadi kosong, hanya ada beberapa orang pegawai yang ada di ruang keuangan dan UKHI. Di lantai 3 hanya ad satu orang di masing-masing ruang UKPBI, PPK dan ruang PBI serta kasubag PBI. Di lantai 4 masing-masing unit PSDKU dan PDD terdapat 3- 4 orang. Pada sore hari, kegiatan diisi oleh UKM drumband mereka menggunakan area parkir belakang lantai 1 untuk berlatih, pada area sebelah kanan UKM Karate juga ikut berlatih di sana. Ruang di lantai 1 yang masih terdapat kegiatan adalah di ruang akademik, dan beberapa mahasiswa masih menunggu di ruang tunggu lantai 1 . Di lantai 2 area yang masih terdapat aktifitas ruang keuangan. Di lantai 3 ruang Pengawas Internal, UKPBI, dan ruang PBI masih terdapat pegawai yang bekerja. Sedangkan di lantai 4 masih ada 6 orang pegawai yang masih bekerja.

Di Tabel 2 yaitu hari Rabu, jumlah pengunjung bangunan tidak sebanyak pada hari Senin, ini terlihat pada lantai 1 jumlah mahasiswa yang menunggu di pagi hari sebanyak 5 orang. Ruang akademik terdapat 6 orang yang bekertja, bagian UPPM terdapat 1 orang yang bekerja dan TU ada 2 orang. Di lantai 2 hampir semua ruang terisi pengunjung baik itu pegawai maupaun pengunjung. Di lantai 3 ruang yang terisi adalah ruang satuan Pengawas internal, ruang PBI, ruang UKPBI, sebanyak 3 orang menunggu dan duduk di koridor. Di lantai 4 hampir semua ruang terisi dengan pegawai, tidak ada aktifitas mahasiswa di sini seperti di hari Senin. Pada siang hari hanya ada 6 pegawai yang bertugas di bagian akademik dan 1 orang di bagian TU. Di lantai 2 di ruang tamu Pudir 1 dan Pudir 3 terdapat 4 orang yang hadir. Bagian kepegawaian terdapat 5 orang di dalamnya bagian keuangan masih terdapat 
2 orang pegawai dan 1 orang mahasiswa. Dan terdapat 2 orang mahasiswa yang menunggu di koridor depan ruang direktur. Di lantai 3 hanya ruang UKPBI dan ruang PBI yang masih ada pegawainya. Terakhir, di lantai 4 terdapat 6 orang pegawai di dalam ruang PSDKU dan PDD. Menjelang sore hari jumlah mahasiswa di ruang tunggu lantai 1meningkat sebnayak 8 orang, dan yang berada di ruang TU sebanyak 2 orang. Pegawai yang masih berada di dalam ruangan adalah di ruang TU, UPPM, dan bagian informasi. Di lantai 2 terdapat 3 orang mahasiswa yang berada di ruang rapat Pudir 1 dan 3, dan 2 orang di ruang Pudir 3. Terdapat 2 orang pegawai di ruang Pudir 2, 1 orang terdapat di ruang keuangan dan 3 orang pegawai di bagian kepegawaian serta 1 orang pegawai dari bangunan lain. Di lantai 3 pegawai yang masih bekerja hanya di ruang UKPBI, Satuan Pengawas internal, dan ruang PBI. Di lantai 4 masih terdapat 5 orang yang bekerja.

Di Tabel 3 pada hari Jumat, jumlah mahasiswa tidak begitu banyak yang berkunjung ke gedung direktorat, hanya ada \pm 5 orang yang berada di lantai 1 . Sedangkan jumlah pegawai yang berada di lantai 1 lebih banyak dari hari sebelumnya. Setiap ruangan terdapat pegawai yang bekerja. Hanya di ruang TUdan UPPM yang terdapat 1 pegawai. Di lantai 2 suasana ruang dan lantai juga sepi, terdapat 2 orang pegawai yang berada di ruang UKHI, Pudir $1 \& 3$. Sedangkan di ruang kepegawaian, ruang Pudir 2 ruang keuangan hanya ada 1 orang yang bekerja. Di lantai 3 ruang UKPBI, PPK, kerumah tanggaan daN ruang PBI terdapat pegawai di dalamnya. Di lantai 4 terdapat 7 orang yang bekerja di lantai tersebut. Pada siang hari cenderung sepi di lantai 1 karena istirahat siang dan sholat jumat, hanya terdapat 1 orang mahasiswa yang berada di ruang tunggu dan hanya ada 1 pegawai di ruangan akademik. di lantai 2 juga sedikit sekali pegawai yaitu hanya ada di ruang kepegawaian, ruang keunagan, dan UKHI masing-masing hanya ada 1 orang. Di lantai 3 ruang-ruang yang masih terisi dengan pegawai adalah ruang PBI, pengawas internal, UKPBI dan kerumahtanggaan. Di lantai 4 masih terdapat 6 orang yang bekerja. Pada akhir jam kerja berakhir jumlah pekerja menjadi bertambah dibandingkan pada pagi hari. Ada 2 orang pegawai di lantai 1 yang menempati masing-masing ruang. Sedangkan di lantai 2 terdapat 4 orang berada di ruang keuangan, 2 orang berada di ruang Pudir 2 . Terdapat 4 orang di ruang kepegawaian dan 1 orang di ruang staf Pudir $1 \& 2$. Di lantai 3 ada 4 orang yang berada di ruang staf PBI, 2 orang di ruang kerumah tanggaan, 2 orang di ruang UKPBI, dan 1 orang di ruang PPK. Sedangkan di lantai 4 terdapat 7 orang yang bekerja di area tersebut. Tabel 4 menunjukkan simbol pengguna ruang atau pelaku pengguna Gedung Direktorat Politeknik Negeri Pontianak yang dibagi berdasarkan jenis kelamin dan lokasi bekerja.

Dari hasil pengamatan place centered mapping di lapangan digambarkan dalam tabel berikut ini.

Tabel 5. Kesimpulan Hasil Amatan Place Centered Mapping

\begin{tabular}{|c|c|c|c|c|}
\hline & Lantai 1 & Lantai 2 & Lantai 3 & Lantai 4 \\
\hline \multirow{5}{*}{$\begin{array}{l}\text { Place } \\
\text { centered } \\
\text { mapping }\end{array}$} & $\begin{array}{l}\text { Pada Hari Senin pagi kegiatan } \\
\text { ramai di lantai } 1 . \text { Ruang paling } \\
\text { ramai adalah ruang tunggu }\end{array}$ & $\begin{array}{l}\text { Pada Hari Senin pagi ruang- } \\
\text { ruang yang ramai adalah ruang } \\
\text { manajemen kampus dan } \\
\text { pimpinan }\end{array}$ & $\begin{array}{l}\text { Pada senin pagi di lantai } 3 \\
\text { hanya ada } 2 \text { ruang yang terisi } \\
\text { oleh pegawai }\end{array}$ & $\begin{array}{l}\text { Pada senin pagi banyak } \\
\text { mahasiswa yang berkumpul di } \\
\text { hall lantai } 4 \text { untuk bersantai- } \\
\text { santai }\end{array}$ \\
\hline & $\begin{array}{l}\text { Pada senin siang suasana ruang } \\
\text { tunggu lebih ramai karena jam } \\
\text { istirahat siang, jumlah pekerja } \\
\text { lebih sedikit disbanding pagi hari }\end{array}$ & $\begin{array}{l}\text { Pada senin siang hampir setiap } \\
\text { ruang kosong karena istirahat }\end{array}$ & $\begin{array}{l}\text { Pada senin siang setiap ruang } \\
\text { terisi oleh } 1 \text { orang pegawai } \\
\text { kecuali PDD dan PSDKU } \\
\text { terdiri dari } 3-4 \text { orang }\end{array}$ & $\begin{array}{l}\text { Pada senin siang terdapat } 1 \\
\text { orang pada tiap ruangan }\end{array}$ \\
\hline & $\begin{array}{l}\text { Pada Senin sore kegiatan di lantai } \\
1 \text { menjadi sepi, tetapi area semi } \\
\text { outdoor dibagian belakang lantai } 1 \\
\text { menjadi ramai karena kegiatan } \\
\text { mahasiswa }\end{array}$ & $\begin{array}{l}\text { Pada senin sore ruang bagia } \\
\text { keuangan masih terlihat } \\
\text { aktifitas di sana }\end{array}$ & $\begin{array}{l}\text { Pada senin sore aktifitas } \\
\text { terjadi di } 3 \text { ruang }\end{array}$ & $\begin{array}{l}\text { Pada senin sore jumlah } \\
\text { pegawai yang bekerja } \\
\text { berjumlah } 6 \text { orang }\end{array}$ \\
\hline & $\begin{array}{l}\text { Pada Rabu pagi jumlah } \\
\text { pengunjung di ruang informasi } \\
\text { tidak sebanyak di hari senin }\end{array}$ & $\begin{array}{l}\text { Pada Rabu pagi hampir semua } \\
\text { ruangan terisi oleh pegawai } \\
\text { maupun pengunjung dari } \\
\text { kalangan mahasiswa maupun } \\
\text { pegawai Gedung lain }\end{array}$ & $\begin{array}{l}\text { Pada rabu pagi jumlah } \\
\text { pegawai yang megisi } \\
\text { ruangan masing-masing } \\
\text { hanya } 1 \text { sisanya berkumpul } \\
\text { di koridor }\end{array}$ & $\begin{array}{l}\text { Pada rabu pagi semua ruangan } \\
\text { terisi pegawai dan tidak ada } \\
\text { aktifitas mahasiswa di sini }\end{array}$ \\
\hline & $\begin{array}{l}\text { Pada Rabu siang jumlah } \\
\text { pengunjung sama dengan jumlah } \\
\text { pengunjung di pagi hari }\end{array}$ & $\begin{array}{l}\text { Pada rabu siang jumlah } \\
\text { pegawai yang bekerja di ruang }\end{array}$ & $\begin{array}{l}\text { Pada rabu siang jumlah } \\
\text { pegawai hanya berfokus pada }\end{array}$ & $\begin{array}{l}\text { Pada rabu siang ruang yang } \\
\text { terisi pegawai hanya PSDKU }\end{array}$ \\
\hline
\end{tabular}




\begin{tabular}{|c|c|c|c|c|}
\hline & $\begin{array}{l}\text { Pada Rabu sore suasana di lantai } 1 \\
\text { semakin sepi, hanya ada security } \\
\text { dan kegiatan mahasiswa di } \\
\text { belakang Gedung }\end{array}$ & $\begin{array}{l}\text { Pudir, runag kepegawaian, dan } \\
\text { ruang keuangan } \\
\text { Pada rabu sore ruang Pudir } 3 \\
\text { dan } 4 \text { yang lebih banyak } \\
\text { dikunjungi oleh mahasiswa. } \\
\text { Selain itu ruang keuangan dan } \\
\text { koridor lantai } 2\end{array}$ & $\begin{array}{l}2 \text { ruang dengan jumlah } \\
\text { pegawai masing-masing } 3 \\
\text { Pada rabu sore masih } \\
\text { terdapat pekerja yang bekerja } \\
\text { di } 3 \text { ruang di lantai } 3\end{array}$ & $\begin{array}{l}\text { dan PDD masing-masing } \\
\text { berjumlah } 3 \text { orang } \\
\text { Pada rabu sore terdapat } 5 \\
\text { orang pegawai yang bekerja } \\
\text { di lantai } 4\end{array}$ \\
\hline & $\begin{array}{l}\text { Pada Jumat pagi jumlah } \\
\text { pengunjung mahasiswa sama } \\
\text { dengan di hari Rabu, tetapi jumlah } \\
\text { pegawai cenderung lebih banyak } \\
\text { di hari sebelumnya }\end{array}$ & $\begin{array}{l}\text { Pada jumat pagi suasana di } \\
\text { lantai } 2 \text { cenderung sepi, hanya } \\
\text { terisi di ruang Pudir dan } \\
\text { bagian kepegawaian }\end{array}$ & $\begin{array}{l}\text { Pada jumat pagi ada } 4 \text { ruang } \\
\text { di lantai } 3 \text { yang terisi oleh } \\
\text { para pegawai }\end{array}$ & $\begin{array}{l}\text { Pada jumat pagi di lantai } 4 \\
\text { hanya } 7 \text { orang yang bekerja }\end{array}$ \\
\hline & $\begin{array}{l}\text { Pada Jumat siang suasana di lantai } \\
1 \text { lebih sepi hanya ada maksimal } \\
1-2 \text { orang yang berada di lantai } 1\end{array}$ & $\begin{array}{l}\text { Pada jumat siang lantai } 2 \\
\text { cenderung sepi, hanya terdapat } \\
1 \text { orang di tiap ruang }\end{array}$ & $\begin{array}{l}\text { Pada jumat pagi ada } 4 \text { ruang } \\
\text { di lantai } 3 \text { yang terisi oleh } \\
\text { para pegawai }\end{array}$ & $\begin{array}{l}\text { Pada jumat pagi di lantai } 4 \\
\text { hanya } 6 \text { orang yang bekerja }\end{array}$ \\
\hline & $\begin{array}{l}\text { Pada Jumat sore jumlah pekerja } \\
\text { menjadi lebih banyak } \\
\text { dibandingkan pada pagi hari }\end{array}$ & $\begin{array}{l}\text { Pada jumat sore ruangan terisi } \\
\text { pada ruang Pudir, keuangan } \\
\text { dan kepegawaian }\end{array}$ & $\begin{array}{l}\text { Pada jumat sore jumlah } \\
\text { pegawai yang bekerja di } \\
\text { lantai } 3 \text { berjumlah } 9 \text { orang }\end{array}$ & $\begin{array}{l}\text { Pada jumat pagi di lantai } 4 \\
\text { hanya } 7 \text { orang yang bekerja }\end{array}$ \\
\hline $\begin{array}{l}\text { Physical } \\
\text { trace }\end{array}$ & $\begin{array}{l}\text { Focus keramaian pada ruang } \\
\text { tunggu dengan jumlah bangku } \\
\text { yang sedikit sehingga membuat } \\
\text { mahasiswa menunggu di luar } \\
\text { sambal duduk-duduk di anak } \\
\text { tangga atau bersender di dinding }\end{array}$ & $\begin{array}{l}\text { Koridor yang memutar } \\
\text { membuat area servis } \\
\text { diletakkan di tengah sehingga } \\
\text { minim pencahayaan dan } \\
\text { penghawaan alami pada } \\
\text { ruangan tersebut }\end{array}$ & $\begin{array}{l}\text { Pada masapenelitian ini } \\
\text { dibuat ruang lantai } 3 \text { tengah } \\
\text { diperbaiki plafondnyakarena } \\
\text { mengalami kebocoran, } \\
\text { suasana di lantai } 3 \text { cenderung } \\
\text { gelap karena koridor tidak } \\
\text { mndapat pencahayaan alami } \\
\text { hanya dibantu dengan } \\
\text { pencahayaan buatan }\end{array}$ & $\begin{array}{l}\text { Pada lantai } 4 \text { terdapat akses } \\
\text { menuju roof top yang dapat } \\
\text { diakses oleh siapa saja } \\
\text { termasuk mahasiswa, hal ini } \\
\text { sangat berisiko dan berbahaya } \\
\text { karena pengamanan roof top } \\
\text { yang masih minim, hanya } \\
\text { pagar tembok dengan } \\
\text { ketinggian } 70 \mathrm{~cm}\end{array}$ \\
\hline
\end{tabular}

Sumber: Penulis, 2019

\section{Analisa Perilaku (Privasi, Ruang Personal dan Teritori) Pengguna Gedung Direktorat Politeknik Negeri Pontianak}

Dinamika psikologis dari perilaku merupakan proses sosial antara privasi, teritori, dan ruang personal. Privasi yang optimal terjadi kerika privasi yang dibutuhkan sama dengan privasi yang dirasakan. Privasi yang terlalu besar menyebabkan orang merasa terasing, sebaliknya privasi terlalu banyak orang lain yang tidak diharapkan, perasaan crowding atau kesesakakan akan muncul sehingga orang merasa privasinya terganggu. Begitu pula dengan ruang personal dan teritori. Pengamatan perilaku tertuju untuk mengamati enam komponen (Sari, 2019):

- Pelaku, merupakan subyek dari pengamatan perilaku, pelaku ini dapat digambarkan ke dalam berbagai cara tergantung tujuan deskripsinya, misalnya individu atau sekelompok orang, profesi atau status sosialnya.

- Kegiatan, yaitu berbagai kegiatan yang dilakukan, kegiatan tersebut mempunyai kaitan antara yang satu dengan yang lain.

- Orang lain yang terlibat, yaitu siapa saja yang terlibat, karena gambaran tentang suatu kegiatan ditentukan juga oleh bagaimana kegiatan itu melibatkan orang lain.

- Hubungan-Hubungan, yaitu hubungan yang spesifik antara pelaku dengan orang lain yang terlibat, hubungan tersebut misalnya berduaan, berkelompok, atau sendirian.

- Konteks, yaitu dalam suasana yang bagaimana, karena orang-orang mempunyai cara-cara bergaul yang berbeda dari satu suasana ke suasana yang lain, misalnya suasana pesta, atau upacara keagamaan.

- Tempat kegiatan, yaitu kegiatan tersebut dilakukan di dalam seting yang bagaimana, karena makna perilaku di dalam suatu seting tertentu akan tergantung dengan kemampuan seting tersebut untuk digunakan.

Dalam konteks privasi ruang-ruang kerja bagi para pegawai Gedung Direktorat Politeknik Pontianak baik di lantai 1 hingga 4 sudah sangat baik, karena dibatasi dengan akses pintu masuk. Namun, dikarenakan ukuran ruang tunggu yang berukuran kecil, maka tidak dapat menampung jumlah mahasiswa yang banyak misalnya pada saat pendaftaran ulang, sehingga menyebabkan mahasiswa 
tidak dapat duduk di kursi yang telah disediakan, akibatnya kebisingan yang diproduksi juga menjadi lebih banyak, kesesakkan dan kepadatan terjadi, hal ini menimbulkan efek ketidaknyaman bagi para pegawai ataupun mahasiswa yang berada di dalam ruangan. Ukuran lantai 1 secara total setengah dari lantai 2, menjadi penyebab terjadinya kesesakkan dan kepadatan, padahal penzonasian ruang yang ada di lantai 1 banyak sekali melibatkan mahasiswa, masyarakat umum yang datang dan bagian kepegawaian lainnya. Sebagai area yang pertama kali diakses dari luar, kenyamanan terhadap ruang sangat diperlukan di lantai ini. Peletakkan dan jumlah furniture seperti kursi tunggu dan area informasi kurang tertata dengan baik. Kedekatan area loket administrasi, ruang tunggu dengan pintu masuk juga sebagai salah satu pemicu kepadatan dalam ruang di lantai 1. Ruang parkir outdoor di belakang lantai 1 dapat dimanfaatkan sebagai solusi untuk memecah kesesakkan den kepadatan pada ruang di lantai 1.

Pada Gedung Direktorat Polnep hanya ditemukan 1 buah tangga sebagai akses menuju lantai berikutnya. Di dalam Gedung juga tidak terdapat tangga darurat, hal ini dapat membahayakan karena apabila terjadi kebakaran akses sirkulasi yang tersedia hanya 1. Ruang parkir belakang Gedung Direktorat di lantai 1 tidak dapat dimaksimalkan dengan baik, dikarenakan mobil-mobil jarang sekali parkir di tempat tersebut, ruangan ini lebih banyak digunakan untuk kegiatan kemahasiswaan seperti UKM ataupun kegiatan penerimaan siswa baru. Walaupun terdapat pintu yang membatasi antara ruang luar dengan dalam, tetap saja secara privasi area tersebut kurang nyaman karena pada saat acara-acara tertentu area tersebut sangat sesak dan sulit untuk dilewati yang mengakibatkan pengunjung atau pegawai harus memutar ke arah pintu depan.
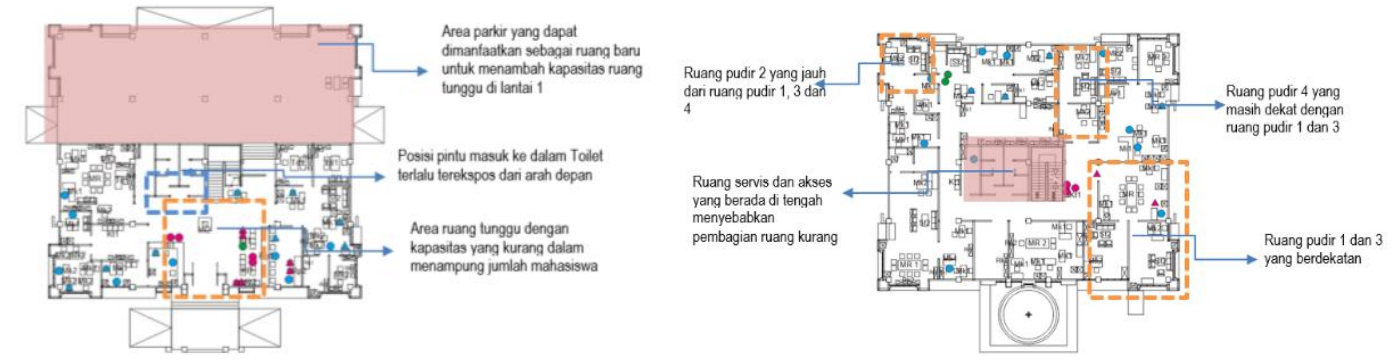

Gambar 9. Analisis Privasi Di Lantai 1 (Kiri), Penzonasian Ruang Di Lantai 2 (Kanan)

Sumber: Penulis, 2019

Untuk di lantai 2 privasi di setiap ruang juga sudah sangat baik, hal ini diperlihatkan dengan sekat-sekat antar ruang. Tetapi penzonasian ruang di lantai 2 masih kurang tepat, peletakkan ruang antara ruang Pudir 1,3,4 dengan ruang Pudir 2 terlalu jauh, harus melewati koridor yang panjang. Peletakkan ruang Pudir 2 dekat dengan ruang keuangan sudah tepat karena deskripsi pekerjaan Pudir 2 menyangkut keuangan, tetapi tidak satu area dengan ruang Pudir-Pudir yang lain. Peletakkan ruang bagian kepegawaian, ruang direktur ataupun UKHI dapat diletakkan pada zona yang sama karena memiliki hirarki yang berbeda. Layout ruang yang mengitari area servis dan akses tangga menyebabkan penempatan ruang kurang terzonasi dengan baik, walaupun secara konektifitas membantu mengakses ruang dengan cepat.

Pada lantai 3 koridor sirkulasi terletak mengelilingi ruang servis dan tangga akses, secara konektifitas koridor tersebut baik karena menghubungkan ruang dengan cepat. Tetapi untuk penzonasian kurang tepat karena menyebabkan ruang-ruang di belakang area servis menjadi jarang dilewati oleh orang-orang atau pengunjung. Secara privasi lebih terjaga tetapi secara jangkauan ruang tidak. Secara psikologi ketika orang telah sampai dari anak tangga terakhir maka secara tanpa sadar mereka akan berbelok ke sebelah kiri karena mencari akses yang yang lebih cepat ke ruang. Pada kasus di lantai 3 ruang sebelah kiri anak tangga adalah ruang rapat besar yang secara penggunaan sangat jarang dipakai, ruang-ruang kerja banyak terletak di depan anak tangga, sisi sebelah kanan dan belakang ruang servis. 


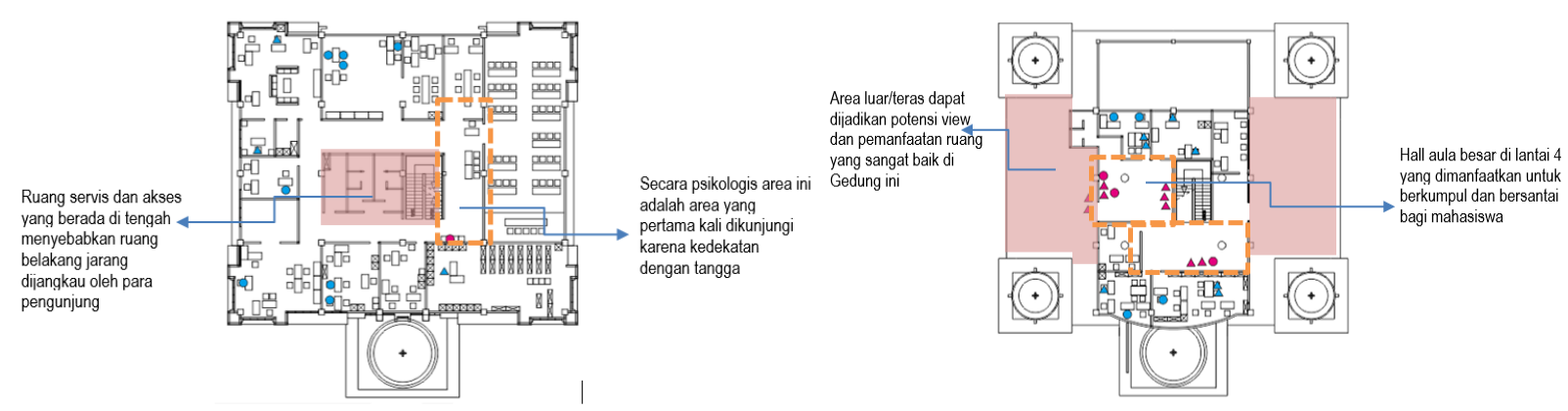

Gambar 10. Privasi Di Lantai 3 (Kiri), Privasi Di Lantai 4 (Kanan)

Sumber: Penulis, 2019

Pada lantai 4 atau lantai paling atas Gedung Direktorat Polnep, dijadikan ruang untuk pegawai hanya $40 \%$ dari luas lantai secara keseluruhan. Sisanya dimanfaatkan sebagai ruang terbuka, dan hall yang luas untuk bersantai. Area ruang terbuka ini banyak dimanfaatkan mahasiswa untuk bersantaisantai ataupun berkumpul. Akibatnya, privasi para pegawai di lantai ini menjadi sedikit terganggu dikarenakan suara yang ditimbulkan oleh para pengunjung terutama mahasiswa yang berkumpul di area hall lantai 4. Tetapi apabila tidak dimanfaatkan dengan baik maka banyak ruang-ruang yang tidak berguna di lantai 4 .

Tingkat ruang personal terlihat pada setiap lantai di Gedung Direktorat Polnep yang telah memisahkan antara ruang publik dan ruang privat dengan baik. Area-area yang memiliki tingkat ruang personal cukup tinggi adalah ruang Direktur dan ruang Pudir. Karena dihubungkan dengan ruang perantara atau ruang staf sebelum memasuki ruang utama. Ruang personal yang tercipta di area publik di lantai 2 adalah pada ruang koridor, di koridor penghubung tersebut diletakkan furniture berupa kursi tunggu. Peletakkan kursi tunggu hanya diletakkan pada 2 titik. Titik pertama adalah di depan ruang Pudir 1 dan 3, sedangkan titik kedua diletakkan di depan ruang Direktur. Jarak kedua bangku tersebut 10,5 meter. Minimnya kursi yang tersedia pada area di depan ruang Direktur dan ruang Pudir menciptakan ruang personal yang cukup tinggi di antara para pengunjung yang menunggu.

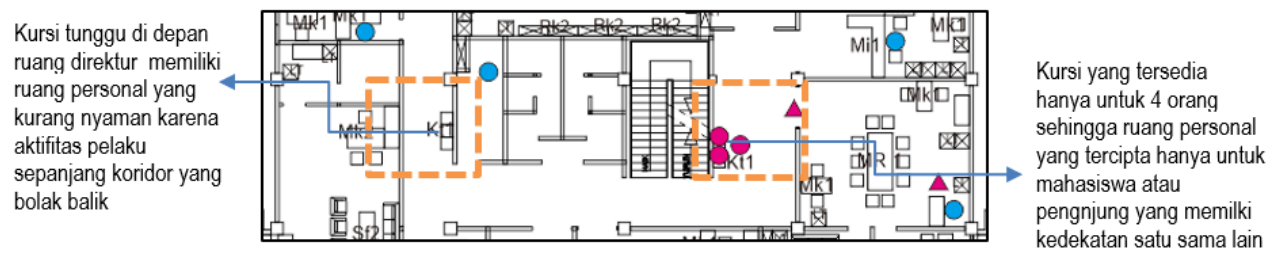

Gambar 11. Peletakkan Kursi Tunggu Di Lt 2 Menyebabkan Ruang Personal Yang Berbeda Pada Individu

Sumber: Penulis, 2019

Pada lantai 1 pembagian zonasi ruang antara TU, bagian akademik, UPPM sudah tepat. Hanya saja pemisah antar ruang tersebut hanya berupa hall yang kecil yang sebagian area tersebut digunakan untuk area informasi. Area hall tersebut akan semakin padat apabila mahasiswa melakukan pendaftaran ulang, yang mengakibatkan jarak personal yang tercipta adalah 1-1,5 meter. Ruang-ruang personal akan semakin banyak terbentuk apabila pelaku atau pengunjung datang secara kelompok. Sehingga individu yang datang sendiri akan mendapatkan ruang personal sisa. 


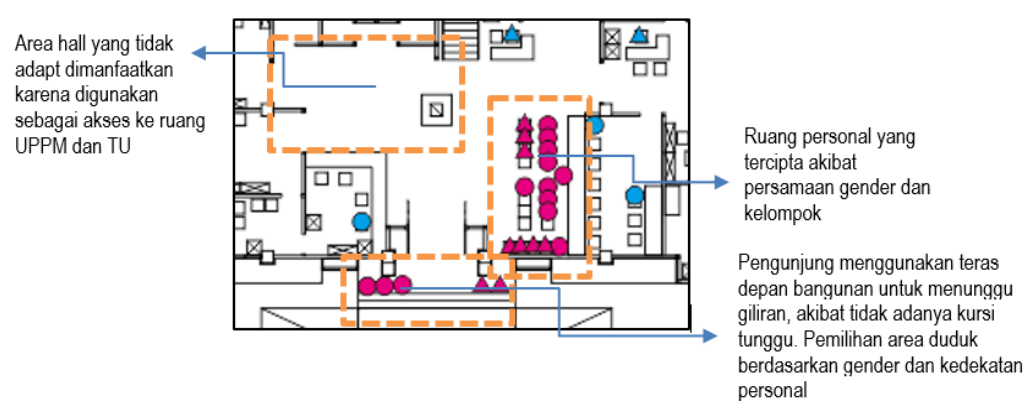

Gambar 12. Ruang Personal Individu Yang Diakibatkan Pemilihan Area Duduk Pada Lantai 1 Sumber: Penulis, 2019

Pada lantai 3 dan 4 layout furniture dan penzonasian ruang sudah baik karena menciptakan ruang personal yang baik. Ruang-ruang di lantai 3 dan 4 bersifat lebih privat dibandingkan ruang-ruang yang ada di lantai 1 dan 2. Area yang dapat diakses oleh public hanya ada di lantai 4 yaitu hall dan ruang luar. Hall yang cukup besar dapat menciptakan jarak personal yang cukup antara individu, tetapi karena area ini memiliki dua buah pintu keluar sehingga mengakibatkan nilai integrasi antara ruang dalam dengan runag luar cukup tinggi, dan hal ini kurang menguntungkan untuk penzonasian di lantai 4, dimana faktor keselamatan dan keamanan menjadi poin utama yang harus diperhatikan.

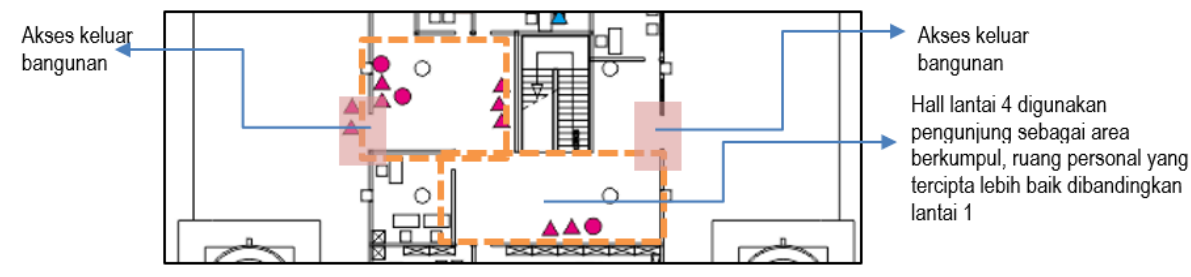

Gambar 13. Ruang Personal Individu Pada Lantai 4

Sumber: Penulis, 2019

Selanjutnya, nilai teritori sangat baik ditunjukkan pada lantai 2 dan 3. Pada lantai 1 menunjukkan teritori yang masih terpecah antara pengelola bangunan dengan pengunjung bangunan, hal diperlihatkan pada area tunggu yang memecah antara zona TU dan zona akademik. sedangkan di lantai 4 hampir sama dengan lantai 1 bahwa terdapat area hall yang cukup besar yang meisahkan ruang pegawai PSDKU dan PDD, sehingga kurang terintegrasi dengan baik walaupun berseberangan.

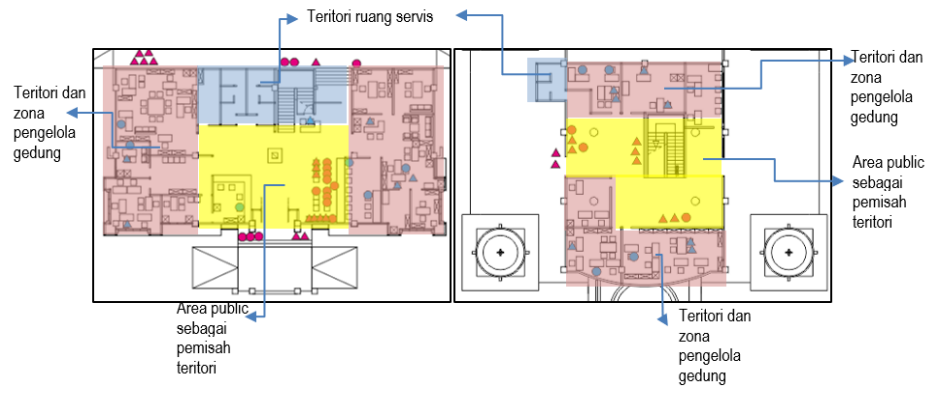

Gambar 14. Teritori Pada Lantai 1 Dan Lantai 4 Sumber: Penulis, 2019 


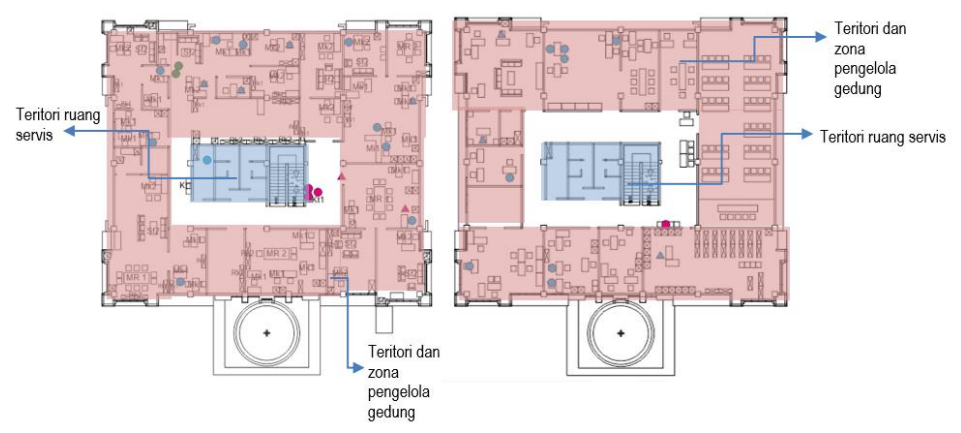

Gambar 15. Teritori Pada Lantai 2 Dan Lantai 3

Sumber: Penulis, 2019

\section{Kesimpulan}

Dari hasil penelitian dan pembahasan dapat disimpulkan bahwa behavior setting dan interaksi yang dilakukan di dalam bangunan Gedung Direktorat Politeknik Negeri Pontianak mengakibatkan penurunan kualitas privasi, ruang personal dan teritori yang ideal dikarenakan faktor-faktor berupa: a) luas ruangan yang tidak mencukupi; b) penzonasian ruang yang tidak efektif satu sama lain; c) standar keselamatan bangunan yang masih minim; c) alur pergerakan penghuni yang kurang terarah terutama pada lantai paling atas; d) peletakkan furniture yang tidak mengacu pada efektifitas ruang; e) Penggunaan fungsi ruang yang kurang maksimal.

Penilaian aspek dan setting perilaku dalam evaluasi purna huni Gedung Direktorat Politeknik Negeri Pontianak dapat dijadikan rekomendasi dan dasar untuk perencanaan dan redesain di masa yang akan datang. Upaya ini dilakukan untuk menilai performa bangunan yang ada dan kemudian dimutakhirkan kembali dengan usulan perencanaan redesain yang baru. Aplikasi dari hasil perencanaan redesain yang baru pada Gedung Direktorat Politeknik Negeri Pontianak dilakukan atas pertimbangan dari identifikasi pola kegiatan pengguna bangunan di setiap lantai yang disesuaikan dengan setting perilaku penghuni. Setting perilaku dapat memberikan gambaran bagaimana perencana akan memberikan rekomendasi redesain yang baik seperti penambahan fasilitas ramah difabel bagi pengguna berkebutuhan khusus, aspek keselamatan dan keamanan bangunan juga harus diperhatikan secara detail, dan pemanfaatan ruang secara optimal.

\section{Daftar Pustaka}

Blyth, A \& Gilby, A. (2006). Guide to Post Occupancy Evaluation. Retrieved from http://www.smg.ac.uk/documents/POEBrochure Final06.pdf

Hadi Wijaya, D. P. ; S. R. (2018). Evaluasi Purna Huni Alun-Alun Kota Malang. Jurnal Mahasiswa Jurusan Arsitektur Universitas Brawijaya, 6(3). Retrieved from http://arsitektur.studentjournal.ub.ac.id/index.ph p/jma/article/view/542

Hay, Rowena, Flora Samuel, K. J. W. \& S. B. (2018). Post-occupancy evaluation in architecture:experiences and perspectives from UK practice. Building Research \& Information, 46(6), 698-710.

Kbbi.co.id. (2019). Arti Kata "Direktorat" Menurut KBBI.

Pena, William. A, S. A. P. (2001). Problem Seeking An Architectural Programming Primer. New York: John Wiley \& Sons Inc.
Pizzuti-Ashby, J. G. (2013). Designing for the Future: A Post-Occupancy Evaluation of the Peter Jones Learning Centre. SIMON FRASER UNIVERSITY.

Preiser, W.F.E., U. S. (1998). Building performance evaluation. In D. Watson, M.J. Crosbie, J.H. Callender (Eds.), Time-saver Standards (7th ed.) (7th ed). New York: McGraw Hill.

Sari, D. P. (2019). Perilaku Pemilihan Tempat Duduk Pada Perpustakaan Jurusan Teknik Arsitektur Universitas Gadjah Mada. JURNAL ARSITEKTUR GRID - Journal of Architecture and Built Environment, 1, 20-29.

Siregar, Aldo Wicaksono, Jenny Ernawati, T. H. (2017). Perancangan Balai Latihan Kerja Industri Dengan Pendekatan Pola Pergerakan Pengguna. Universitas Brawijaya.

Sudibyo, S. (1989). Aspek Fungsi dan Teknis Post Occupancy Evaluation dan Beberapa Metodologi Penelitian. Jakarta: Universitas Trisakti Press. 
Syafriyani, Sangkertadi, J. O. W. (2015). Evaluasi Purna Huni (EPH): Aspek perilaku ruang dalamSLB YPAC Manado. S.l. : Media Martasain, 12(No.3, November 2015).

Yudi Nugraha B, A. D. T. (2013). Penelitian Pada Substansi Environment Behavior (EB) Dalam Arsitektur. Jurnal Ilmiah Program Studi Teknik Arsitektur. http://repository.gunadarma.ac.id/id/eprint/581 Zeisel, J. (1981). Inquiry by Design, Tools for Environment - Behavior Research. Cambridge: Cambridge University Press. 